\title{
Pemanfaatan Lingkungan Terhadap Media Pembelajaran Bahasa Indonesia
}

\author{
Abrar Ridha/18016059 \\ abrar180600@gmail.com
}

Pemanfaatan lingkungan merupakan salah satu media pembelajaran yang baik untuk diterapkan dalam proses belajar, karena dapat menumbuhkan minat dan semangat peserta didik. Hal ini dapat diterapkan dalam mata pelajaran bahasa Indonesia. Karena siswa bisa mengamati apa yang ada di dalam lingkungan dan menjadikan apa yang siswa lihat sebagai salah satu sumber inspirasi untuk membuat suatu karya sastra. Menurut Rivers (dalam Ramadhan et al, 2019), sebagai guru bahasa,kami adalah guru yang paling beruntung, semua mata pelajaran adalah milik kami. Apa pun yang ingin dikomunikasikan oleh siswa kami, apa pun yang ingin mereka baca, adalah materi pelajaran kami. Menurut Hauchild, Poltavthenko dan Stoller (dalam Ramadhan et al, 2019), guru bahasa berada dalam posisi unik untuk mempromosikan kesadaran lingkungan.

Menurut Mitsuki dan Lai (dalam Ramadhan et al, 2019), di seluruh dunia, setiap orang menghadapi masalah lingkungan yang serius, seperti pemanasan global, hujan asam, perusakan lapisan ozon, pencemaran lingkungan, kerusakan alam, dan hilangnya keanekaragamn hayati dapat mengancam kehidupan generasi mendatang. Masalah lingungan disebabkan oleh aktivitas manusia yang ceroboh dan intensif di daerah alami untuk meningkatkan kualitas hidup mereka. Aspek yang lebih mengancam adalah ketidaksadaran pengaruh manusia di lingkungan mereka. Kerusakan lingkungan menghasilkan krisisekologis yang akan menyebabkan serangkaian masalah dengan sumber daya alam, iklim,polusi, makanan, dan ekonomi. Masyarakat yang hidup saat ini dihadapkan dengan masalah lingkungan yang menibulkan terjadinya bencana alam.

Menurut Buldur dan Omeroglu (dalam Ramadhan et al, 2019), pendidikan lingkungan penting untuk meningkatkan sikap dan kesadaran siswa terhadap lingkungan. Pendidikan lingkungan harus dirancang untuk berkontribusi pada pengembangan kognitif, emosional, linguistik dan psikomotor siswa, dan memungkinkan mereka untuk mengembangkan sikap positif terhadap lingkungan Selain itu, guru juga harus mengembangkan kemampuan siswa untuk memahami, mengkritik, dan berpartisipasi secara rasional dalam setiap wacana tentang masalah lingkungan. Menurut Unyar dan Ensar (dalam Ramadhan et al, 2019), menggunakan materi pembelajaran dalam pembelajaran teks dapat memicu minat siswa dalam mempelajari bahasa dan berimplikasi dapat meningkatkan pengetahuan siswa tentang lingkungan hidup. 
Menurut Jacobs G M dan Cates K (dalam Ramadhan et al, 2019), tujuan dari pendidikan lingkungan adalah untuk membuat siswa berpartisipasi dalam melindungi lingkungan adalah membuat siswa berpatisipasi dalam melindungi lingkungan. Menurut Kollmuss A danAgyeman J, Schultz P W, Shriver C, Tabanico J J, dan KhazianA M, Xehua Z, serta ÇokçaliskanH and ÇelikÖ (dalam Ramadhan et al, 2019), agar siswa berpatisipasi dalam melindungi lingkungan, penting untuk mengembangkan pengetahuan tentang lingkungan, kesadaran lingkungan dan perubahan perilaku terhadap lingkungan. Individu harus didorong untuk tidak memandang lingkungan sebagai sesuatu yang harus dieksploitasi untuk tujuan mereka, tetapi sebagai aset berharga yang layak dilindungi untuk kelangsungan hidup manusia.

Menurut Mitsuki, Nkwetisma dan Nieblas Oritz (dalam Ramadhan et al, 2019), bahwa setiap orang memiliki tanggung jawab yang sama untuk mengatasi masalah ini. Karena kerusakan lingkungan bukan disebabkan dari tempat tertentu, tetapi bisa berasal dari lingkungan sekitar. Kerusakan tidak hanya mempengaruhi kehidupan masa depan, tetapi jugasaat ini. Di seluruh dunia banyak metode telah diterapkan untuk menyelesaikan masalah lingkungan, seperti kebijakan pemerintah, seruan kepada masyarakat, gerakan pecinta alam, dan mmperkuat peraturan pemerintah. Namun, metode ini tidak cukup efektif untuk mengurangi masalah lingkungan. Mengembangkan individu yang sadar dan bertanggung jawab terhadap lingkungan diperlukan untuk mengatasi masalah ini sehingga lingkungan yang berkelanjutan dan kualitas hidup lebih baik.

Menurut Obasoro,Olinloye, dan Ilensami (dalam Ramadhan et al,2019), siswa perlu memiliki pengalaman yang baik dalam memahami dan mengatasi setiap perubahan global dan lingkungan masyarakat.Menurut Begman B,G (dalam Ramadhan et al,2019), berhubungan dengan itu guru juga memiliki peranan yang penting dalam mengajarkan materi lingkungan kepada siswa.Guru dalam materi lingkungan yang diajarkan guru menjadikan guru sebagai model yang tepat dalam memahami materi lingkungan.Selain itu, siswa juga turut penting berperan dalam merespos dan menerapkan tentang pemahamannya dalam mempelajari materi lingkungan.Karena tanpa adanya penerapan dari siswa maka pembelajaran materi lingkungan dalam pembelajaran yang diberikan oleh guru, maka tujuan pembelajaran tersebut tidak akan tercapai.

Lai (dalam Ramadhan et al, 2019) mengatakan masalah lingkungan secara inheren tidak dapat dipisahkan dari kesadaran lingkungan, nilai-nilai, dan sikap orang. Ini mendorong negara untuk mulai menilai pendidikan lingkungan. Pendidikan lingkungan hidup adalah suatu proses untuk membangun populasimanusia di dunia yang sadar dan peduli terhadap 
lingkungan total (keseluruhan) dan segala masalah yang berkaitan dengannya, dan masyarakat yang memiliki pengetahuan, keterampilan, sikap dan tingkah laku, motivasi serta komitmen untuk bekerja sama, baik secara individu maupun secara kolektif, untuk dapat memecahkan berbagai masalah lingkungan saat ini, dan mencegah timbulnya masalah baru (UNESCO, Deklarasi Tbilisi, 1977).

Dari data yang dihasilkan mengenai materi lingkungan dalam pembelajaran bahasa Indonesia dapat diterapkan dalam kehidupan sehari-hari, 54,1\% menyatakan sangat setuju dan $45,9 \%$ menyatakan setuju. Pembelajaran berbasis lingkungan bertujuan untuk membuat siswa berpartisipasi dalam melindungi lingkungan, 54,1\% menyatakan sangat setuju dan 45,9\% menyatakan setuju. Dalam pembelajaran bahasa Indonesia materi lingkungan lebih mudah dicontohkan daripada teori ilmiah. 59,5\% menyatakan sangat setuju dan 40,5\% menyatakan setuju. Materi pembelajaran bahasa Indonesia mengenai lingkungan merupakan topik menarik dan beragam untuk diajarkan, 43,2\% menyatakan sangat setuju dan 56,7\% menyatakan setuju. Memiliki pengetahuan mengenai lingkungan dalam pembelajaran bahasa Indonesia dapat memperluas pengetahuan dan keterampilan menulis, 56,8\% menyatakan sangat setuju, 40,5\% menyatakan setuju dan 2,7\% menyatakan kurang setuju. Materi lingkungan lebih memudahkan peserta didik dalam memahami pembelajaran bahasa Indonesia, 43,2\% menyatakan sangat setuju, 51,4\% menyatakan setuju dan 5,4\% menyatakan kurang setuju. Materi lingkungan dalam pembelajaran bahasa Indonesia merupakan hal tidak penting, 21,6\% menyatakan sangat setuju, 24,3\% menyatakan setuju, 10,8\% menyatakan kurang setuju dan 43,2\% menyatakan tidak setuju. Lingkungan dapat dijadikan sebagai sumber pembelajaran bahasa Indonesia, 51,4\% menyatakan sangat setuju dan 48,6\% menyatakan setuju. Lingkungan sebagai sumber pembelajaran bahasa Indonesia menjadi lebih kaya karena lingkungan yang dapat dipelajari beraneka ragam, 40,5\% menyatakan sangat setuju dan 59,5\% menyatakan setuju. Pemanfaatan lingkungan merupakan media pembelajaran bahasa Indonesia yang baik untuk diterapkan dalam proses pembelajaran, 40,5\% menyatakan sangat setuju dan 59,5\% menyatakan setuju.

Dari hasil pengisian angket yang telah penulis lakukan dapat disimpulkan bahwa mahasiswa dan pelajar setuju pemanfaatan lingkungan merupakan salah satu media pembelajaran yang baik. Pemanfaatan lingkungan sebagai media pembelajaran lebih bermakna disebabkan para siswa dihadapkan langsung dengan peristiwa dan keadaan yang sebenarnya secara alami, sehingga lebih nyata, lebih faktual, dan kebenarannya dapat dipertanggung jawabkan. Disamping itu, guru juga berharap siswa akan lebih akrab dengan lingkungan sehingga menumbuhkan rasa cinta akan lingkungan sekitarnya. 


\section{Daftar Rujukan}

Bergman, B.G. (2016). Assessing impacts of locally designed environmental education projects on students' environmental attitudes, awareness, and intention to act Environmental Education Reseach 22(4) 480-503

Buldur, A. and Ömeroglu, E. (2018). An examination of the relationship between pre-school children's and their teacher' attitute and awareness towards the environment Journal of Education and Learning 7(2) 221-9.

Hauchild, S., Poltavthenko, E. And Stoller, F. L. (2012. Going green: Menging environmental education ang language instruction English Teaching Forum Number2 $2-13$

Jacobs G M and Cates K.(2012). Global education in second language and teaching International Journal of Physical and Social Sciences 2 1-22

Kollmuss A and Agyeman J. (2002). Mind the gap: Why do people act enviconmentally andwhat are the barriers to pro-environmental behavior Environmental Education Research 239-60

Lai, C.S. (2018). A study of fifth graders' environmental learning outcomes in Taipei International Journal of Research in Education and Science4(1) 252-61

Mitsuki I. (2017) Beyond the limitations of environmental education in Japan Educational Studies in Japan: International Yearbook 3-14

Nieblas-Ortiz E C, Acrcos-Vega J L and Sevilla-Garcia J J 2017 The construction of an environmental management model based on sustainability indicators on a higher education institution in Mexico Higher Education Studies 715-22

Nkwetisma C M.(2011) EFL/ESL and environmental education: towards an eco applied linguistic awareness in Cameroon World Journal of Education 1(1) 110-18

Ramadhan, S., Sukma, E., \& Indriyani, V. (2019). Environmental education and disaster mitigation through language learning. IOP Conference Series: Earth and Environmental Science, 314

Obasoro C B,Olinloye O A,and Illansami A A.2013 The importance of environmental education to secondary education level in Akure South local goverment area, Ondo State Nigeria,Africa Research Reviiew 7 (4) 298-306

Uyar Y and Ensar F 2016 Does mother tongue education support development of environmental literacy in Turkey? An analysis of Turkish course book International Journal of Environmental \& Science Education 11(1) 1-8 